\title{
Design Phase of Gamification Framework for Hazard Identification Training in Construction Industry
}

\author{
https://doi.org/10.3991/ijim.v16i02.27405 \\ Khew Kai Ren, Norhazren Izatie Mohd ${ }^{(凶)}$, Kherun Nita Ali, Shamsulhadi Bandi, \\ Fuziah Ismail \\ Faculty of Built Environment, Universiti Teknologi Malaysia, Johor, Malaysia \\ norhazren@utm.my
}

\begin{abstract}
Game has been proven an effective approach tool to improve learning and has become a new tool for training delivery. The development of the gamification framework involves integrating design processes which are input, process, and output. The design phase is considered essential to guide the flow of the gamification framework. It offers a safer, interactive, and entertaining learning environment for construction-related workers. This paper aims to report on the approach to design a gamification framework for hazard identification training in Construction using Garris's Input-Process-Outcome game model as the basis. It focuses on the three main design elements: instructional design, game characteristic, and user characteristic. The study outlines two objectives: (1) to identify the game's attributes and Gagne's Nine Events Instructional Methods Design which supports effective learning, and (2) to determine the user's characteristics of self-directed learning. This study focused on designing the Design phase, which consists of instructional design, game characteristics and user characteristics. Mixed methods were used to extract the attributes and elements of the Design phase. Content analysis was carried out to determine the instructional design model and game attributes, 12 attributes have been identified, and Gagne's Nine Events Instructional Methods Design can support effective learning. Meanwhile, a questionnaire survey is used to determine the user's self-directed learning and decision-making style, where 319 construction-related workers responded. The results showed that construction-related workers belong to the independent learners' category and are inclined to 'vigilant' and 'brooding' types of decision-making style. Following the aim of this paper, these findings were incorporated into the design phase of the game framework.
\end{abstract}

Keywords_-game, safety training, hazard, framework

\section{$1 \quad$ Introduction}

Construction workers are constantly exposed to numerous occupational hazards of different kinds and levels of complexity in every project they engage in. Besides that, the working environment on the construction site exposed construction-related workers to the hazard. Therefore, they must have the knowledge and the ability to handle hazards on a construction site. Therefore, there is a need for training modules that can provide the knowledge to construction workers to acquire the skills necessary for occupational 
and environmental safety on-site. However, current safety training still lacks hands-on approaches, which is theory-oriented [1]. This is due to the nature of the construction environment itself. Hands-on approaches are irrelevant to be applied for certain types of hazards. Hence, the need for training assisted technology is indispensable. The game approach can offer visual training, an immersive and safer learning environment, hands-on training with scenario-based flexibility, and affordable training delivery [2], [3]. This can be beneficial in training construction-related workers. With this approach, hazard training becomes more flexible in time, cost and health [1], [4], [5]. The approach also enables the construction-related workers to practice their skills using the "trial and error" exercise with their existing knowledge and experience [6]. This is where the games can become the missing link between knowledge and hands-on training. This study has adopted the Input-Process-Outcome (IPO) model as the basis for developing the game framework.

\section{Input-process-output model}

IPO game model was developed by Garris, Ahlers, \& Driskell (2002). [7] The aim is to develop a self-directed and self-motivated learner through exciting activities in achieving the outcome. The traditional IPO learning model emphasises single-trial learning, where a learner performs a task over a single trial [8]. Although the current model adopts the input-process-output framework, the critical component is the game cycle triggered by specific game features.

The primary purpose of gameplay is not about how users play a game but to draw users into playing a game repeatedly. For instance, a young person engaged in a computer game may often have to be told to turn off the game or stop playing. Besides that, the game cycle can be viewed as repeating steps, which indicates that the gameplay involves repeated judgement-behaviour-feedback loops. The gameplay cycle can lead to user judgements or reactions such as increased interest, enjoyment, involvement, or confidence. These reactions lead to more remarkable persistence or intensity of effort. In addition, these behaviours result in system feedback on performance in the game context [9]-[11]. Thus, the game cycle defines a computer gameplay characteristic that engages users in repetitive play and continually returns to the game activity. It is this feature of computer gameplay that train professionals to capture and incorporate instructional applications. Figure 1 shows the composition of the Input-ProcessOutcome framework.

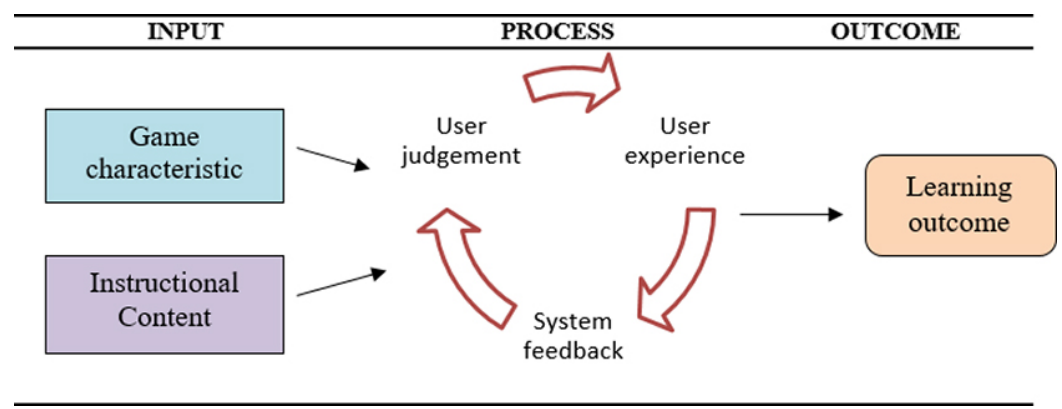

Fig. 1. Input-process-outcome model (Garris et al. 2002) 


\section{Methodology}

This research was conducted using two research techniques which are content analysis and a survey. In the first phase of the study, content analysis was conducted to determine the suitability of Gagne's Instruction design method in balancing the design of the profound game framework. Besides that, these methods also fulfil the necessity to determine and categorise existing serious game attributes according to educational perspectives. For this study's first objective, the deductive content analysis study was carried out to check the suitability of Gagne's nine instructional events to be incorporated into the serious game framework. The keywords and the benefit from both were generated in the analysis of the study's content. Besides that, attributes of the serious game were ascertained through the review of previous studies. These attributes needed to be categorised according to the educational view as a feature in the serious game framework. Subsequently, the content analysis approach was administered to convey the implicit messages from the analysis.

In the second objective, a survey approach was adopted. A set of questionnaires was designed and used to determine the level of self-directed learning and decisionmaking style among construction-related workers. This data collection aims to understand construction-related workers capability in planning and self-directness learning. Three hundred and nineteen (319) participants have taken part in this survey, fifty-two (52) respondents participated in the online survey, and the rest were participating during training organised by NIOSH Johor.

\section{Design phase component for gamification framework}

In designing the design phase, three main elements must be included: (1) game attributes, (2) user characteristics, and (3) instructional learning design. Each element included in the design phase will cause a change in the process and the outcome. Hence, the design phase is essential to guide the flow of the gamification framework.

\subsection{Instructional content}

One of the essential elements in the design phase is the instructional learning design. This element becomes the essence of structuring the cycle of learning in the game framework. A Systematic Literature Review (SLR) was conducted on five instructional design models: ADDIE, Hanaffin and Peck, ASSURE, The Dick and Carey (DC) model, and Gagne's nine events. The target group for this research is the adult and the behaviour taken by construction-related workers in handling hazards on construction sites. According to Kruse, (2008), [12] Gagné's nine events of instruction model focus on the outcomes or behaviours from training. Besides, this model has contributed significantly to instructional technology, especially in designing web-based instruction [13]. Hence, Gagne's nine instructional events are considered compatible with adult behaviours and adult learning styles (Kruse 2008; Jono et al., 2012; Gökdemir et al., 2013). 
Ference \& Vockell (1994) [14] agreed that Gagne's events of instruction are compatible with adult learners characteristics. They have developed instructional software for an adult using Gagne's events of instruction. Adult learners are mature and responsible learners who only want to learn what they want to know. They already have a mindset to learn something that can give benefit them. This can be supported by Gagne's nine instructional instruction event number one, which is gaining attention and informing learners of the objectives. The third instruction is to stimulate recall of prior learning. It is related to the cumulative knowledge and experience that have been collected previously by the adult learner.

Table 1. Summary of merging between the adult characteristic and Gagne's event of instruction

\begin{tabular}{|c|c|c|c|c|c|c|}
\hline & $\frac{z}{0}$ & 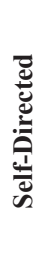 & 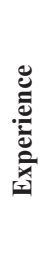 & 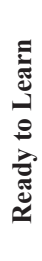 & 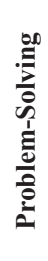 & 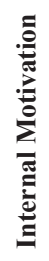 \\
\hline Gagne's nine events of instruction & \multicolumn{6}{|c|}{ Adult learning criteria } \\
\hline Gaining Attention & & & & $\mathbf{x}$ & & \\
\hline Inform learners of the objectives & $\mathbf{x}$ & & & & & \\
\hline Stimulating recall of prior learning & & & $\mathbf{x}$ & & & $\mathbf{x}$ \\
\hline Present the stimulus & & & & & $\mathbf{x}$ & \\
\hline Provide learner guidance & & $\mathbf{x}$ & & & & \\
\hline \multicolumn{7}{|l|}{ Elicit student performance } \\
\hline \multicolumn{7}{|l|}{ Provide feedback } \\
\hline Assess Performance & & & & & & $\mathbf{x}$ \\
\hline Enhance retention and transfer & & & $\mathbf{x}$ & & & \\
\hline
\end{tabular}

For the rest of Gagne's nine event instructions, events are related to the cycle of the learning process. This entire event provides the instructor with guidance for learning. Therefore, they need to keep up the trainee's both internal and external motivation. Giving motivation is the essential problem-solving skill that will ensure the continuity of the learning cycle. Therefore, according to Knowles (1980), Merriam (2010) and Dzeng \& Wang (2017), [15-17] the adult learner have a high motivation to learn. They are self-direct learners who only need guidance, and they also seek problem-based learning, not direct learning. As a result, the merging between the adult characteristic and Gagne's events of instruction is a good balance. Table 1 summarises how the characteristics of adult learners merge with Gagne's events of instruction.

Hence, deductive content analysis has been carried out to determine whether Gagne's instructional design methods are suitable instructional methods for this framework. Hence, fourteen documents which consist of articles and a technical report, were analysed. These articles were scrutinised and grouped based on the pre-determined codes. As a result, four principal codes have been determined, i.e. [1] target group, 
[2] application, [3] purpose and [4] outcome. Table 2 shows the finding of deductive content analysis for Gagne's Instructional design.

Table 2. Content analysis Gagne's instructional design

\begin{tabular}{|c|l|l|c|}
\hline \multicolumn{1}{|c|}{ Key Point } & \multicolumn{1}{c|}{ Journal and Publication } & Frequency \\
\hline 1 & Target group & & \\
\hline a & School learning & {$[18],[19],[20]$ and [21] } & 4 \\
\hline b & Higher learning & {$[18],[22],[23],[24],[25],[21]$ and [26] } & 7 \\
\hline c & Adult learning & {$[14],[27],[28],[29]$ and [30] } & 5 \\
\hline 2 & Application & & \\
\hline a & Learning/Training & {$[20],[21],[28]$ and [30] } & 4 \\
\hline b & Online learning-website & {$[27],[22],[25]$ and [26] } & 4 \\
\hline c & Game & {$[18],[29],[31]$ and [19] } & 4 \\
\hline d & Multimedia & {$[24]$} & 1 \\
\hline e & Learning software & {$[14],[23]$} & 2 \\
\hline $\mathbf{3}$ & Focus & & 6 \\
\hline a & User characters & {$[14],[28],[22],[24],[20]$ and [21] } & 12 \\
\hline b & Provide feedback & {$[14],[27],[28],[22],[29],[31],[23],[24],[25]$,} & \\
\hline c & Motivation & {$[20],[21]$ and [30] } & 6 \\
\hline d & Entertainment & {$[18],[18],[22],[31],[19]$ and [26] } & 5 \\
\hline 4 & Outcome & & \\
\hline a & Transfer skills-motor skills & {$[14],[23]$ and [19] } & \\
\hline b & Transfer knowledge & $\begin{array}{l}{[14],[18],[22],[20] \text { and [30] }} \\
{[19],[26] \text { and [30] [29], [31], [23], [24], [25], }}\end{array}$ & 12 \\
\hline c & Behaviour/attitudes & {$[28],[22],[29]$ and [21] } & 4 \\
\hline
\end{tabular}

This instructional design method will improve the learning instruction with a systematic approach for problem-solving, feedback characteristics and improve instructional design and development management by monitoring/controlling function. Besides that, instructional development is a systematic process that focuses on improving learning and instruction effectiveness in various educational environments.

All the nine events of instructions will guide the learning process in the game training module. The learning cycle starts by gaining attention from the learner after informing them about the study's objectives and, next, recalling the prior learning by extracting the existing knowledge. After that, activities or learning will begin. During this stage, learning guidance, eliciting performance, and providing feedback were enclosed together. Finally, learning performance will be assessed at the end of the learning cycle to enhance retention and transfer knowledge and skills.

The findings of this study acknowledge that this instructional design method can be applied to the various level of learners such as school learners, higher learners and adult learners. Besides that, it can also be implemented in various learning approaches conventional learning, online learning, game, multimedia, and learning software [32]. 
This flexibility of the instructional will be able to generate a diverse approach in training delivery. Furthermore, Gagne's nine events instructional design methods will allow the designer to design a training module according to the purpose of the study. For example, it can enhance learners' motivation, provide feedback to the learner, change user characteristics or behaviours, and entertainment [20]. This study is designed to train hazard identification and decision-making skills in handling hazards on the construction site.

What is more that, this instructional design method also offers learning outcomes according to the learning goal. Transferring skills, transferring knowledge, and changing attitudes or behaviours is the most expected learning outcome generated from this instructional [33]. Consequently, it is expected that this framework will enhance the construction-related worker's ability to identify the hazard and take wise action in handling hazards on the construction site. Besides that, it will also lift their motivation to keep learning and boost their self-confidence in facing hazards on the construction site. For this reason, Gagne's nine events instructional design method was adopted to design the game framework for hazard identification.

\subsection{Game characteristics}

While the instructional design is to guide the cycle of the learning process, the game attributes are the coordinator to deliver the learning process effectively. Hence, the second element was to determine the game attributes to support the practical game training module. From the systematic literature studies, it has been found that twenty-six game attributes are commonly used in game development (refer to Table 2). However, in their study, Bedwell et al. (2012) indicated that Wilson et al. (2009) new attributes are a fraction of Malone characteristics. Hence, those attributes have been modified according to Malone characteristics, reducing game attributes into only nineteen. The affected attributes are the optimal level of difficulty (Wilson: adaption), performance feedback (Wilson: assessment), challenge (Wilson: Conflict) and control (Wilson: interaction equipment/inter-personal/social).

However, this framework aims to train users in making safer decision-making in handling hazards on the construction site. Thus, these attributes need to be categorised according to educational perspectives. Therefore, to create a practical training module, all these game attributes complement learning theories (behaviourism, cognitivism, constructivism and experiential learning). The study conducted by Mohd, Ali, Faiz, et al., (2019) and Yusoff, Crowder, \& Gilbert (2010a) [34-35] indicated twelve game attributes determined to support Gagne's instructional design in designing a practical 
game framework. Table 3 and Table 4 show the game attributes and the extraction of game attributes from each learning theory.

There are three game attributes derived from behaviours theory, which focuses on improving user behaviour, especially in designing the aim and activity. From this theory, three main attributes are Interaction, Reward, and Practice and Drill.

Based on the concept behind this theory, all these attributes can enhance skills and motivate the user to keep playing the game. For example, the interaction attribute role ensures the user's ability to adapt and manipulate elements that allow game changes in response to learner actions. Besides, it will ensure that each game level will match the learner's skills level, especially in attaining challenges with possible solutions. The second attribute is practice and drill, which provides repetition and constant rehearsal during the learning process. This attribute enables the user to reinforce memory and support with rewards elements to motivate the learning process. The second theory, which Cognitivism theory, is related to how to deliver the learning process. There are four attributes related to this theory: incremental learning, linearity, attention span, and transfer of learning skills. All these attributes act as guidance in designing the learning process. For example, designing the learning plot should start from the novice to the master level and specific rules and goals. Besides that, it also will direct the flow of knowledge delivery, especially in the arrangement of learning content. Well, design learning content enables the user to focus throughout the whole game learning process.

After plot and learning content has been appropriately designed, the Constructivism theory will help users construct knowledge from their experiences. Hence, scaffolding attributes will encourage learners in constructing knowledge using the trial-and-error approach. This approach can create re-examine and re-assess learning approach, which allows them to learn through experience. 


\begin{tabular}{|c|c|c|c|c|c|c|c|c|c|c|c|}
\hline$\underset{\sim}{2}$ & səs!̣.Idns & & & & & & $x$ & $x$ & $x$ & $x$ & \\
\hline$\ddot{2}$ & 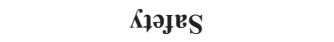 & & & & & & $x$ & & $x$ & & \\
\hline$\stackrel{4}{4}$ & иоџฺฺนวsә.лdәу & & & & & & $x$ & & $x$ & & \\
\hline 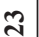 & !'nu!̣S א.rosuəs & & & & & $x$ & $x$ & $x$ & $x$ & $x$ & \\
\hline $\mathcal{2}$ & SSว.ภô0.. & & & & & & $x$ & $x$ & $x$ & $x$ & \\
\hline$\vec{\sim}$ & 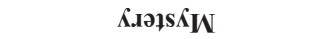 & & & & & $\rtimes$ & $x$ & $x$ & $x$ & $x$ & \\
\hline 고 & บо!ตวоТ & & & & & & $x$ & $x$ & $x$ & $x$ & \\
\hline 2 & 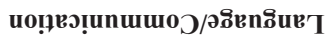 & & & & & & $x$ & $x$ & $x$ & $x$ & $x$ \\
\hline$\stackrel{\infty}{1}$ & ([ห!ฺоS) чо!ฺ७.ләри & & & & & & $x$ & $x$ & $x$ & $x$ & $x$ \\
\hline$\Xi$ & 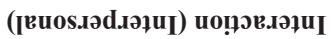 & & & & & & $x$ & $x$ & $x$ & $x$ & $x$ \\
\hline 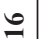 & 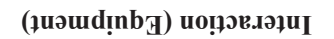 & & & & & & $x$ & $x$ & $x$ & $x$ & $\rtimes$ \\
\hline$n$ & səs!̣.Idns & & & & & & & $x$ & & & \\
\hline \pm & तseque & & & & & $x$ & $x$ & $x$ & $x$ & $x$ & $\rtimes$ \\
\hline 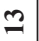 & диәшіssəss & & & & & & $x$ & $x$ & $x$ & $x$ & $x$ \\
\hline ㄱ & uо!ฺвұdepV & & & & & & $x$ & $x$ & $x$ & $x$ & \\
\hline$\exists$ & คฺ!๒யоว & & & & & & $x$ & $x$ & $x$ & $x$ & $x$ \\
\hline 으 & บоџенц!оW & & & & $x$ & & & & & & \\
\hline$a$ & †хәџบоว & & & $x$ & & & & & & $x$ & \\
\hline$\infty$ & S[EoD & & & $x$ & $x$ & $x$ & $x$ & $x$ & $x$ & $x$ & $x$ \\
\hline$n$ & səןny & & & $x$ & & $\rtimes$ & $x$ & $x$ & $x$ & $x$ & $x$ \\
\hline ๑ & 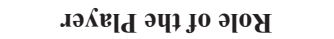 & & $x$ & & & & $x$ & & $x$ & $x$ & \\
\hline$n$ & 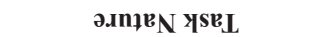 & & $x$ & & & & & & & & \\
\hline$\nabla$ & 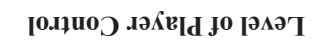 & & $x$ & & & & & $x$ & & $x$ & \\
\hline$m$ & [0.1ฺน0ว & $x$ & & & & & $x$ & & $x$ & $x$ & \\
\hline$N$ & 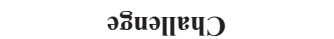 & $x$ & & & & $x$ & $x$ & $x$ & $x$ & $x$ & $x$ \\
\hline \multirow[t]{2}{*}{-} & אุ!̣so!̣..nว & $x$ & & & & & & & & & \\
\hline & & 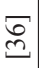 & $\bar{n}$ & 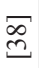 & à & $\stackrel{8}{9}$ & $\vec{\Xi}$ & 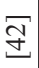 & $a$ & $\stackrel{\mathfrak{g}}{ \pm}$ & 寻 \\
\hline
\end{tabular}


Table 4. Game attributes based on learning theory [34], [45]

\begin{tabular}{|c|c|c|}
\hline Theory & Attributes & Description \\
\hline \multirow[t]{3}{*}{ Behaviourism } & Interaction & Engagement in learning \\
\hline & Reward & Incentives for the learner \\
\hline & Practice and drill & $\begin{array}{l}\text { Learning activities and exercises within the } \\
\text { game }\end{array}$ \\
\hline \multirow[t]{4}{*}{ Cognitivism } & Incremental learning & $\begin{array}{l}\text { The learning material is delivered in an } \\
\text { incremental way }\end{array}$ \\
\hline & Linearity & Learning is arranged sequentially \\
\hline & Attention span & Duration for learning concentration \\
\hline & Transfer of learnt Skilled & $\begin{array}{l}\text { Applying Skills to new learning based on } \\
\text { previous learning }\end{array}$ \\
\hline \multirow[t]{2}{*}{ Constructivism } & Scaffolding & Support and help during the learning \\
\hline & Learner control & $\begin{array}{l}\text { Self-learning and active learning based on } \\
\text { learner pace }\end{array}$ \\
\hline \multirow[t]{3}{*}{ Experiential Learning } & $\begin{array}{l}\text { Accommodating the learner's } \\
\text { style }\end{array}$ & Learning process to suit learner preferences \\
\hline & Scenario-based learning & $\begin{array}{l}\text { Learning where the learner can relate what } \\
\text { is being learnt within the game to the outside } \\
\text { world. }\end{array}$ \\
\hline & Intermittent feedback & Just-in-time feedback for learning \\
\hline
\end{tabular}

Similar to constructivism theory, experiential learning theory also proposes learning through experience but needs to accommodate the learner's style, using scenario-based learning and providing intermittent feedback. Accommodating the learner's style attribute will enrich the game design based on user preferences, incorporated with the learning environment designed similar to the real-life situation. This attribute will adequate users to experience a similar feeling when dealing with the actual situation in the natural working environment. Besides that, the user also will get prompt feedback by checking their progress of learning through the intermittent feedback attributes. The learning activities can be designed according to Gagne's instructional design guideline from the game attributes. Table 5 shows the learning activities extracted from Gagne's nine events instructional integration with the game attributes in designing the gamification framework. 
Table 5. The game attributes are based on learning theory [34], [45]

\begin{tabular}{|c|c|}
\hline \multicolumn{2}{|c|}{ Game Attributes (Based on Educational Perspective) } \\
\hline Learning Activities & Game \\
\hline \multirow[t]{2}{*}{ Get learner's attention } & Scenario-based learning \\
\hline & Incremental learning \\
\hline Inform learner of the learning outcome & Linearity \\
\hline Extract some information the learner already knows & Learner control \\
\hline \multirow[t]{2}{*}{ Game activity and lesson to be learnt } & Accommodating the learner's style \\
\hline & Attention span \\
\hline Help and support learners. & Scaffolding \\
\hline \multirow{2}{*}{$\begin{array}{l}\text { Ask the learner to do what has been taught by acting } \\
\text { within the game. }\end{array}$} & Interaction \\
\hline & Transfer of learnt skills \\
\hline Inform learner of his performance & Intermittent feedback \\
\hline $\begin{array}{l}\text { Evaluate the learner on his knowledge of the subject } \\
\text { matter. }\end{array}$ & Reward \\
\hline Assist learners in remembering and applying new skills. & Practice and drill \\
\hline
\end{tabular}

\subsection{User characteristic}

Input-Process-Outcome (IPO) in Figure 1 shows only two essential elements in the design phase: the instructional design and the game attributes. However, to design a practical training module that fulfils the user's needs and requirements, the characteristic user element also needs to be infused into the Design phase. Hence, the purpose of the third element is to determine the user's characteristics in understanding their ability in self-directed learning and decision-making styles. Both elements will be mixed to ensure the user can learn by themselves and make a safer decision in handling hazards in the gaming environment.

According to Candy \& Brookfield (1991), [46] individuals who enjoyed self-directed learning have high moral, emotional, and intellectual autonomy. They further asserted that an individual ready to learn by himself is a context-free person. This individual already masters technical skills and consists of three major components: identifying learning purposes, locating learning resources, and managing learning endeavours. Thus, to determine the capability and ability among construction-related workers regarding the level of self-directed learning, five broad areas (awareness, learning strategies, learning activities, evaluation and interpersonal skills) were adopted [47]. From the findings, the construction-related workers have a high level of self-directed learning, which implies that all workers can learn by themselves. Besides that, they also have the know-how skills to take the initiative to determine their learning needs, formulate learning goals, and choose resources for learning. Moreover, using existing experience, they can decide on suitable learning strategies and assess the learning outcome according to their needs. These findings show the construction-related workers can choose their own need of learning and learn by themselves. 
The second element is to determine the decision-making style among the construction-related worker. This is because the decisions taken are significantly different. However, many experts have proven that every individual has the same tendency to solve problems [48]. Since the focus of this study is to understand the construction-related worker's decision-making style, eight styles were adopted from Leykin and DeRubeis (2010) study [49]. The findings indicate that five groups are skill workers, supervisors, Consultants, the Management Team, and Trainees vigilant in making decisions. Meanwhile, general workers and semi-skill workers are categorised under the brooding style for making a decision.

Unexpected findings have given a new perspective on construction-related workers, General Worker in particular. General workers are categorised as brooding style, defined as a thinker who is always worried about making a decision. This style means that they are aware of their capability and responsibility. However, they are always worried about making a decision [50]. Hence, this finding is surprisingly different from their role on the site. Usually, at the construction site, they are followers who take orders from the top management. Therefore, they are not required in making a big decision and have a limited scope of work [50]. Nevertheless, ironically, this group is the riskiest group involved in accidents on construction sites.

Meanwhile, skills workers, supervisors, consultants, management teams, and safety trainees are more vigilant in deciding. This group are independent people who have insights and are very careful in protecting their interests. Nevertheless, they are loyal and always alert to criticism (Mohd et al., 2019). However, both styles need to be improved and changed because time is the essence in handling hazards. Therefore, the construction-related workers must take immediate action to prevent accident occurrences on the construction site.

\section{Conclusion}

The Design phase of a game framework is essential in understanding the construction-related worker's self-directed learning and decision-making styles. There are three main elements in the Design phase, i.e. instructional design, game characteristic and user characteristic. The study identified 12 attributes and verified Gagne's nine events instructional methods design to support effective learning. As for user characteristics, the construction-related workers belong to the independent learners' category and are inclined to 'vigilant' and 'brooding' types of decision-making style. Figure 2 below shows the integration between all three elements in the Design phase: Gagne's nine events Instructional Method design, the game attributes, and user characteristics. This entire element will become the guideline in designing the game training module for hazard identification. Hence, it is essential to integrate all the elements in designing the design phases of the game. 


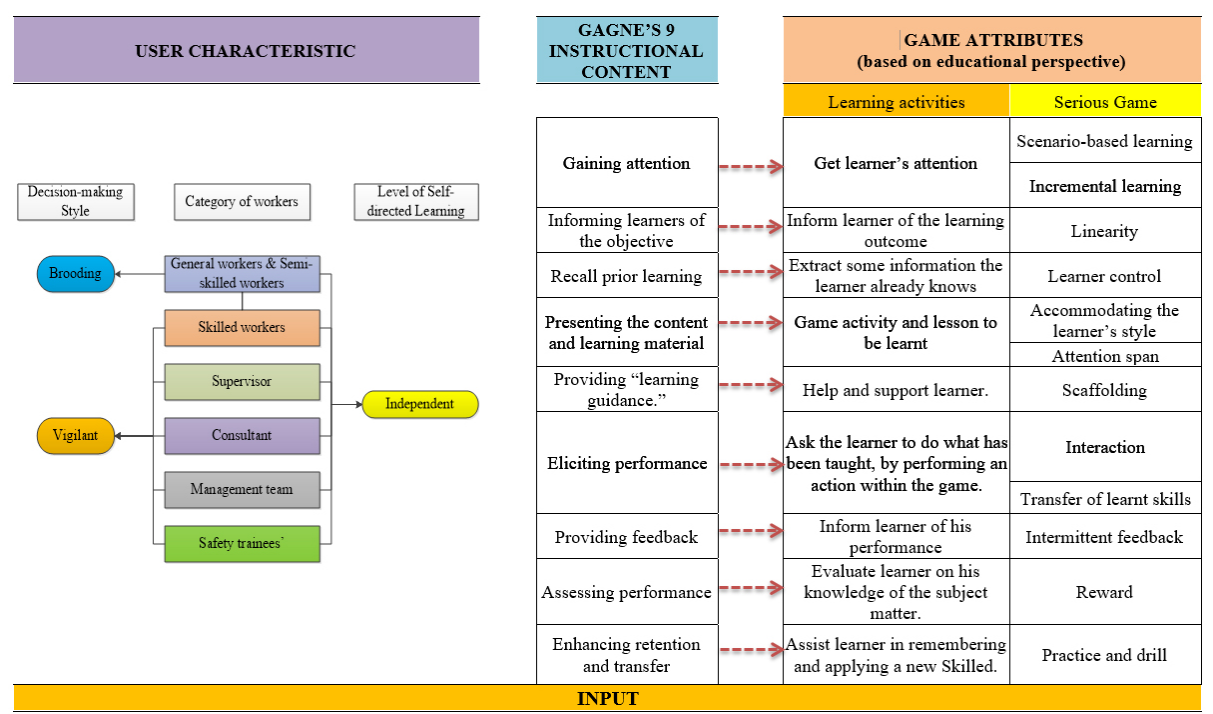

Fig. 2. Input in the game framework

\section{Acknowledgement}

This article is part of ongoing research titled "Gamification Framework as a Training Approach to Enhance Construction Workers Skills, Safety and Wellness", funded under the Fundamental Research Grant Scheme-FRGS 2018/2019 by the Ministry of Education, Malaysia.

\section{$7 \quad$ References}

[1] N. I. Mohd and K. N. Ali, "Addressing the Needs of Gaming Approach in Hazard Identification Training," in 2014 International Conference on Teaching and Learning in Computing and Engineering, 2014, pp. 212-215. https://doi.org/10.1109/LaTiCE.2014.48

[2] J. Díaz-Ramírez, "Gamification in Engineering Education-An Empirical Assessment on Learning and Game Performance," Heliyon, vol. 6, no. 9, p. e04972, 2020. https://doi. org/10.1016/j.heliyon.2020.e04972

[3] C. Crawford, "Serious Games: Improving Public Policy Subjectivity and Simulation," Pennsylvania Avenu, Washington, DC, 2003.

[4] C. Girard, J. Ecalle, A. Magnan, and A. Magnant, "Serious Games as New Educational Tools: How Effective are They? A Meta-Analysis of Recent Studies," J. Comput. Assist. Learn., vol. 29, no. 3, p. 12, Jun. 2013. https://doi.org/10.1111/j.1365-2729.2012.00489.x

[5] J. Wall and V. Ahmed, "Use of a Simulation Game in Delivering Blended Lifelong Learning in the Construction Industry-Opportunities and Challenges," Comput. Educ., vol. 50, no. 4, pp. 1383-1393, 2008. https://doi.org/10.1016/j.compedu.2006.12.012 
[6] A. Uysal, "Commitment to Multiplayer Online Games: An Investment Model Approach," Comput. Human Behav., vol. 61, pp. 357-363, 2016. https://doi.org/10.1016/j. chb.2016.03.028

[7] R. Garris, R. Ahlers, and J. E. Driskell, "Games, Motivation, and Learning: A Research and Practice Model," Simul. Gaming, vol. 33, no. 4, pp. 441-467, 2002. https://doi. org/10.1177/1046878102238607

[8] R. Garris and R. Ahlers, “A Research and Practice Model,” Simul. Gaming, vol. 33, no. 4, pp. 441-467, 2002. https://doi.org/10.1177/1046878102238607

[9] W. L. Bedwell, D. Pavlas, K. Heyne, E. H. Lazzara, and E. Salas, "Toward a Taxonomy Linking Game Attributes to Learning: An Empirical Study," Simul. Gaming, vol. 43, no. 6, pp. 729-760, 2012. https://doi.org/10.1177/1046878112439444

[10] M. Sailer, J. U. Hense, S. K. Mayr, and H. Mandl, "Computers in Human Behavior How Gamification Motivates: An Experimental Study of the Effects of Specific Game Design Elements on Psychological Need Satisfaction," Comput. Human Behav., vol. 69, pp. 371380, 2017. https://doi.org/10.1016/j.chb.2016.12.033

[11] G. Petri and C. G. von Wangenheim, "How Games for Computing Education are Evaluated? A Systematic Literature Review," Comput. Educ., vol. 107, pp. 68-90, 2017. https://doi. org/10.1016/j.compedu.2017.01.004

[12] K. Kruse, “Gagne's Nine Events of Instruction: An Introduction," Star. pp. 2-5, 2008.

[13] B. H. Thomas, "A Survey of Visual, Mixed, and Augmented Reality Gaming," Comput. Entertain., vol. 10, no. 3, pp. 1-33, 2012. https://doi.org/10.1145/2381876.2381879

[14] P. Ference and E. Vockell, "Adult Learning Characteristics and Effective Software Instruction,” Educ. Technol. Brook ..., vol. 34, no. 6, pp. 25-31, 1994.

[15] M. S. Knowles, "The Modern Practice of Adult Education, from Pedagogy to Andragogy What is Andragogy?," in The Modern Practice Of Adult Education, From Pedagogy to Andragogy What Is Andragogy?, Revised an., Cambridge Adult Education, 1980, pp. 40-59.

[16] S. B. Merriam, "Adult Education-Adult Learning, Instruction and Program Planning," Adult Learn., pp. 12-17, 2010. https://doi.org/10.1016/B978-0-08-044894-7.00003-8

[17] R.-J. Dzeng and P.-R. Wang, "C-Negotiation Game: An Educational Game Model for Construction Procurement and Negotiation," Autom. Constr., vol. 75, pp. 10-21, 2017. https:// doi.org/10.1016/j.autcon.2016.11.010

[18] K. Amr, "Constructing Knowledge through Games: Essential Factors for an Effective Educational Game," World Conf. Educ. Multimedia, Hypermedia Telecommun. 2007, vol. 2007, no. 1, pp. 1601-1609, 2001.

[19] J. L. Tan, D. H. L. Goh, R. P. Ang, and V. S. Huan, "Participatory Evaluation of an Educational Game for Social Skills Acquisition," Comput. Educ., vol. 64, pp. 70-80, 2013. https:// doi.org/10.1016/j.compedu.2013.01.006

[20] İ. Çalışkan, "A Case Study about Using Instructional Design Models in Science Education," Procedia-Soc. Behav. Sci., vol. 116, pp. 394-396, 2014. https://doi.org/10.1016/j. sbspro.2014.01.228

[21] M. D. Ilie, “An Adaption of Gagne's Instructional Model to Increase the Teaching Effectiveness in the Classroom: The Impact in Romanian Universities," Educ. Technol. Res. Dev., vol. 62, no. 6, pp. 767-794, 2014. https://doi.org/10.1007/s11423-014-9353-6

[22] B. Teoh and T. Neo, "Interactive Multimedia Learning: Students' Attitudes and Learning Impact in an Animation Course," Turkish Online J. Educ. Technol., vol. 6, no. 4, pp. 28-37, 2007.

[23] L. R. Gano, "Fitting Technology to the Mathematics Pedagogy: Its Effect on Students' Academic Achievement," J. Coll. Teach. Learn., vol. 8, no. 11, p. 29, 2011. https://doi. org/10.19030/tlc.v8i11.6505 
[24] M. N. H. H. Jono, A. A. Aziz, M. Ibrahim, and N. M. Noh, "Instructional Design and Learning Theory on the Development of C++ Programming Multimedia Content," Procedia-Soc. Behav. Sci., vol. 67, no. 0, pp. 335-344, 2012. https://doi.org/10.1016/j.sbspro.2012.11.336

[25] A. Gökdemir, Ö. Akdemir, and Ö. F. Vural, "Using Gagne's Nine Events in Learning Management Systems," Procedia-Soc. Behav. Sci., vol. 106, pp. 3268-3272, 2013. https://doi. org/10.1016/j.sbspro.2013.12.376

[26] F.-T. Leow and M. Neo, "Redesigning for Collaborative Learning Environment: Study on Students' Perception and Interaction in Web 2.0 Tools," Procedia-Soc. Behav. Sci., vol. 176, pp. 186-193, 2015. https://doi.org/10.1016/j.sbspro.2015.01.460

[27] P. A. Hannon et al., "Gagne and Laurillard's Models of Instruction Applied to Distance Education: A Theoretically Driven Evaluation of an Online Curriculum in Public Health," Int. Rev. Res. Open Distance Learn., vol. 3, no. 2, pp. 140-154, 2002. https://doi.org/10.19173/ irrodl.v3i2.105

[28] M. B. Kinzie, "Instructional Design Strategies for Health Behavior Change," Patient Educ. Couns., vol. 56, no. 1, pp. 3-15, 2005. https://doi.org/10.1016/j.pec.2004.02.005

[29] A. Subaih, S. Maddock, and D. Romano, "Developing a Serious Game for Police Training," Handb. Res. Eff. Electron. Gaming Educ., pp. 451-477, 2009. https://doi.org/10.4018/9781-59904-808-6.ch026

[30] L. Cheung, "Using an Instructional Design Model to Teach Medical Procedures," Med. Sci. Educ., vol. 26, no. 1, pp. 175-180, 2016. https://doi.org/10.1007/s40670-016-0228-9

[31] A. Hirumi, B. Appelman, L. Rieber, and R. Van Eck, "Game Design as a Collaborative Process," TechTrends, vol. 54, no. 5, 2010.

[32] R. R. Bhavani, “A Novel Approach for Training Crane Operators,” pp. 10-13, 2016.

[33] M. G. Brown, "Blended Instructional Practice: A Review of the Empirical Literature on Instructors' Adoption and Use of Online Tools in Face-to-Face Teaching," Internet High. Educ., vol. 31, pp. 1-10, 2016. https://doi.org/10.1016/j.iheduc.2016.05.001

[34] N. I. Mohd, K. N. Ali, A. Faiz, A. Ahmad, S. Shafiei, and J. Bahru, "Serious Game Attributes for the Construction of a Hazard Identification Framework," Int. J. Interact. Mob. Technol., vol. 12, no. 7, 2019. https://doi.org/10.3991/ijim.v12i7.9647

[35] A. Yusoff, R. Crowder, and L. Gilbert, "Validation of Serious Games Attributes using the Technology Acceptance Model," 2nd Int. Conf. Games Virtual Worlds Serious Appl. VS-GAMES 2010, pp. 45-51, 2010. https://doi.org/10.1109/VS-GAMES.2010.7

[36] T. W. Malone, "Toward a Theory of Intrinsically Instruction Motivating," Cogn. Sci., vol. 5, no. 4, pp. 333-369, 1981. https://doi.org/10.1207/s15516709cog0504_2

[37] M. E. Gredler, "Educational Games and Simulations: A technology in Search a (research) Paradigm," in Handbook of Research for Educational Communications and Technology, New York: Simon \& Schuster Macmillan, 1996, pp. 521-540.

[38] H. Leemkuil, T. De Jong, and S. Ootes, "Review of Educational Use of Games and Simulations," 2000.

[39] J. Juul, "The Game, the Player, the World: Looking for a Heart of Gameness," Proc. Lev. Up Digit. Games Res. Conf., pp. 30-45, 2002.

[40] R. Garris, R. Ahlers, and J. E. J. Driskell, "Games, Motivation, and Learning: A Research and Practice Model,” Simul. Gaming, vol. 33, no. 4, pp. 441-467, Dec. 2002. https://doi. org/10.1177/1046878102238607

[41] K. A. Wilson et al., "Relationships between Game Attributes and Learning Outcomes: Review and Research Proposals," Simul. Gaming, vol. 40, no. 2, pp. 217-266, 2009. https:// doi.org/10.1177/1046878108321866

[42] D. Pavlas, W. Bedwell, S. R. Wooten, K. Heyne, and E. Salas, "Investigating the Attributes in Serious Games that Contribute to Learning," Hum. Factors Ergon. Soc. Annu. Meet. Proc., vol. 53, no. 27, pp. 1999-2003, 2009. https://doi.org/10.1177/154193120905302705 
[43] S. Heintz and E. L. Law, "Game Elements-Attributes Model: a First Step towards a Structured Comparison of Educational Games," DiGRA 2015 Divers. Play, 2015.

[44] S. L. Marlow, E. Salas, L. B. Landon, and B. Presnell, "Eliciting Teamwork with Game Attributes: A Systematic Review and Research Agenda," Comput. Human Behav., vol. 55, pp. 413-423, 2016. https://doi.org/10.1016/j.chb.2015.09.028

[45] A. Yusoff, R. Crowder, and L. Gilbert, "Validation of Serious Games Attributes using the Technology Acceptance Model," in 2nd International Conference on Games and Virtual Worlds for Serious Applications, VS-GAMES 2010, 2010, pp. 45-51. https://doi.org/10.1109/ VS-GAMES.2010.7

[46] P. Candy and S. Brookfield, "Self-Direction for Lifelong Learning: A Comprehensive Guide to Theory and Practice," p. 567, 1991.

[47] R. T. Owen, "Self-Directed Learning in Adulthood: A Literature Review," p. 57, 2002.

[48] B. L. Johnson, Jr., and S. D. Kruse, "Introduction: Leadership, Decision Making, and Underexplored Issues in Decision Making," in Decision Making for Educational Leaders: Underexamined Dimensions and Issues, New York: State University of New York Press, Albany, 2012, pp. 3-22.

[49] Y. Leykin and R. J. DeRubeis, "Decision-Making Styles and Depressive Symptomatology: Development of the Decision Styles Questionnaire," Judgm. Decis. Mak., vol. 5, no. 7, pp. 506-515, 2010.

[50] N. I. Mohd, K. N. Ali, S. S. Ebrahimi, and A. F. Azizi, "Understanding the Level of SelfDirected Learning and Decision-Making Style of Construction-Related Workers," Int. J. Interact. Mob. Technol., vol. 13, no. 7, pp. 44-53, 2019. https://doi.org/10.3991/ijim. $\underline{\mathrm{v} 13 \mathrm{i} 07.10749}$

\section{Authors}

Khew Kai Ren is a 1st Year postgraduate student from Universiti Teknologi Malaysia. He is currently pursuing his PhD under the department of Quantity Surveying, Faculty of Built Environment and Surveying. Prior to this, he received his bachelor's degree in Quantity Surveying from UTM. His primary research interests are in the field of Gamification, and Construction related fields.

Norhazren Izatie Mohd is a senior lecturer at Quantity Surveying Department, Faculty of Built Environment in Universiti Teknologi Malaysia. She is the member of Royal Institution Surveyor Malaysia (RISM) and Building Information Modelling Research Group (BIMRG). Her research interests are gamification, destructive technology, construction safety, and adult training.

Kherun Nita Ali is an Associate Professor at the Faculty of Built Environment, Universiti Teknologi Malaysia. She is the Head of Building Information Center for Digital Innovations and Solutions (BIMCDIS), Faculty of Built Environment, Universiti Teknologi Malaysia, Johor Bahru. Having been also the Head of BIM Research Group in UTM, she is currently active in researches and publications related to Building Information Modelling (BIM). Her recent works with her research team are Enhancing Cost Planning and Control through 5D BIM, BIM Deployment Plan for QS Firms, Facilities Management (7D) BIM, Managing Safety through BIM and GIS BIM. Other research works also include 4.0 IR in higher education and Mobile Augmented Reality for teaching and learning Quantity Surveying courses. She is a member of Royal Institutions of Surveyors Malaysia (RISM) BIM Technical Committee since its establishment in 2011. 
Shamsulhadi Bandi is a senior lecturer at Quantity Surveying Department, Faculty of Built Environment in Universiti Teknologi Malaysia. He is the member of Royal Institution Surveyor Malaysia (RISM) and Building Information Modelling Research Group (BIMRG). His research interests are gamification, destructive technology, quantification, economic and quantity surveying practices.

Fuziah Ismail is a senior lecturer at Quantity Surveying Department, Faculty of Built Environment in Universiti Teknologi Malaysia. She is the member of Royal Institution Surveyor Malaysia (RISM) and Building Information Modelling Research Group (BIMRG). Her research interests are gamification, destructive technology, contruction technology, and sustainability.

Article submitted 2021-10-07. Resubmitted 2021-11-21. Final acceptance 2021-11-25. Final version published as submitted by the authors. 